\section{“. . . for the times they are a-changin"}

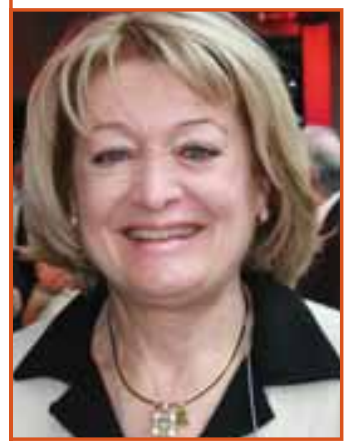

\author{
by Nicole Moreau
}

"Come writers and critics who prophesize with your pen ..."** Fortunately, you don't need to be a prophet to know that in IUPAC even and odd years have important differences. In the even years-like this one-membership changes take place that were approved the previous year.

As IUPAC is a dynamic organization, with a changing and growing membership, efforts are periodically made to improve its functioning. The changes carried out for this purpose are generally not abrupt, but smooth. For instance, in 1999 the establishment of the project system was a huge modification, but the Finance Committee's proposal to add unspent project funds to the Strategic Opportunity Fund helped ease the transition. The smaller changes can make a major difference too: The Streamline Committee's suggestion to make a detailed agenda for meetings has greatly improved their efficiency. And I could cite more examples, such as the round table experiment at the 2007 GA in Torino, now fully adopted, or the Union's further involvement in the International Chemistry Olympiad.

Odd years at IUPAC involve an important event: Council's election of a new vice president at the General Assembly. For Council members, this may seem like a small change that results in a new public face for the Union. However, for the officers, Executive Committee, Bureau, executive director, and staff of the Secretariat, the changes following the elections are a necessary disruption. For the Secretary General and the Treasurer, whose terms are for four years and renewable for another four, a new vice president every two years is still a major change.

Since the IUPAC president's "life expectancy" is only two years, the officers of the union play a bit of musical chairs every January of an even year. With the arrival of the new vice president the former vice president becomes president, the president becomes past president, and the past president retires. IUPAC was certainly smart to institute the role of past president since it would be a little embarrassing and sad for the incoming president to push out the former president. Fortunately, with the former president on the scene, the new president can benefit from his/her experience. In my case, I look forward to benefitting from our past president's cheerful nature and highly efficient and energetic style. Clearly, I won't be alone on the dreadful "Dr. Moreau's Island" because I know that I can count on my predecessor as well as the more "stable" elements of the Union, which include Secretary General David Black, Treasurer John Corish, Executive Director John Jost, and the Secretariat staff.

Of course, the president is not the only "fresh blood." As the newest of the officers, incoming vice presidents are hopefully less sceptical or blasé. This year, what an unusual and interesting situation as the incoming president is European and the past president and vice president are Asian! But as times are changing, l'll lose my mentor of sorts who was president when I became an officer and who was so friendly, so helpful, and so reliable. This is, of course, Bryan Henry, whom IUPAC will greatly miss. Fortunately, Bryan has professional reasons to stay in touch with us; since he is still the IUPAC representative on ICSU, our relationship will be sustained.

\section{Despite what some detractors might say, life within IUPAC will change after IYC.}

There is another change coming, and a very big one: Remember, a year ago, in November 2008, we were all awaiting word on the UN's decision about the International Year of Chemistry. And since we were told that some months would pass before the UN would give its advice, following the favorable one from UNESCO, we were not really in a state of expectation. Yet, just before the end of the year, on 30 December, the UN's declaration of the 2011 International Year of Chemistry arrived, as a beautiful New Year's gift. So, now that we are in the throes of preparing for IYC, the change I refer to is upon us: Despite what some detractors might say, life within IUPAC will change after IYC.

After 2011, the vessels of the Union will flow with a vivid new fluid. For so long, so many of us in IUPAC have said "we have to change the public image of chemistry, we have to more deeply involve industry, we have to make politicians know what chemistry can do to sustain our world, and we have to convince 
young people that chemistry can be their future and can provide them with useful and exciting jobs." Now that the opportunity is here, we must take full advantage. I am rather confident, when I see, through meetings, discussions, or e-mail exchanges, both globally and in my own country, how deeply most Adhering Organizations and chemical societies are involved. In addition, I am encouraged to see the numerous ideas for celebrating the year that have arisen from all corners of the world.

. I am

imploring you

to find ways to

diversify and

increase our

funding sources,

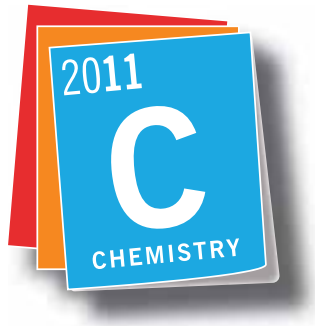

to be able to successfully fund IYC celebrations.

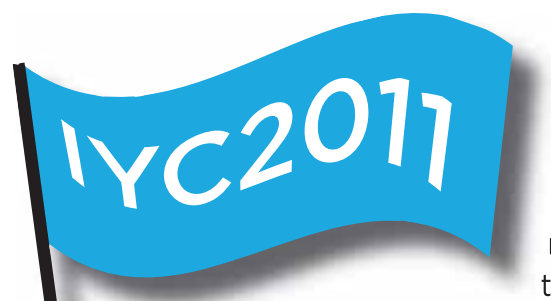

Of course, the big problem, particularly in the midst of an economic downturn, is the funding for each

participating country and for IUPAC itself. But, as your president is an indefectibly optimistic person, she trusts all of us to successfully manage this odorless but indispensable material. The paper for banknotes and alloys for coins-this is chemistry, is it not? But please, do not think that I am encouraging you to become counterfeiters, but rather I am imploring you to find ways to diversify and increase our funding sources, to be able to successfully fund IYC celebrations.

I wish all of you a very happy, fruitful, and active New Year, the last one before the arrival of the firstever international year of chemistry! And "Keep your eyes wide open. The chance won't come again.”*

Nicole J. Moreau <nj.moreau@free.fr> is IUPAC president starting this January 2010. She has been an elected member of the Bureau since 2000, a member of the Executive Committee since 2006, and vice president for 2008-2009. She is also general secretary of the French National Committee for Chemistry.

*The Times They Are a-Changin is singer-songwriter Bob Dylan's third studio album, released in January 1964 by Columbia Records.

\section{0-2011 IUPAC}

\section{Bureau Membership}

\section{Officers}

Prof. Nicole Moreau, France President

Prof. Kazuyuki Tatsumi, Japan Vice President

Prof. David Black, Australia Secretary General

Prof. John Corish, Ireland Treasurer

Prof. Jung-II Jin, Korea Past President

\section{Elected Members}

Mr. Colin Humphris, United Kingdom

Dr. Anders Kallner, Sweden

Prof. Werner Klein, Germany

Prof. Ram Lamba, Puerto Rico

Prof. Stanislaw Penczek, Poland

Prof. Elsa Reichmanis, United States

Prof. Natalia Tarasova, Russia

Prof. Maria C.E. van Dam-Mieras, Netherlands

Prof. Itamar Willner, Israel

Prof. Qi-Feng Zhou, China/Beijing

\section{Division Presidents}

Prof. A. James McQuillan, New Zealand Physical and Biophysical Chemistry Division

Prof. Robert D. Loss, Australia Inorganic Chemistry Division

Prof. Gerrit J. Koomen, Netherlands Organic and Biomolecular Chemistry Division

Prof. Christopher Ober, United States Polymer Division

Dr. Ales Fajgelj, Slovenia Analytical Chemistry Division

Prof. Nicola Senesi, Italy

Chemistry and the Environment Division

Prof. Douglas M. Templeton, Canada Chemistry and Human Health Division

Prof. Richard M. Hartshorn, New Zealand

Chemical Nomenclature and

Structure Representation Division

\section{Other Standing Committee Chairs}

Prof. Leiv K. Sydnes, Norway

CHEMRAWN Committee

Prof. Peter G. Mahaffy, Canada

Committee on Chemistry Education

Dr. Michael J. Dröscher, Germany

Committee on Chemistry and Industry

(Executive Committee members are denoted in bold). 